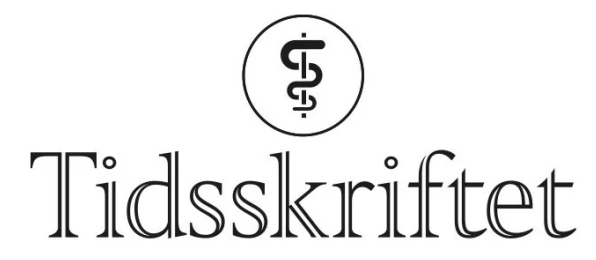

DEN NORSKE LEGEFORENING

\title{
Der den høyeste formen for ros er fravær av kritikk
}

\author{
KOMMENTAR OG DEBATT
}

\section{OLE KRISTIAN LOSVIK}

Ole Kristian Losvik (f. 1982) er turnuslege ved St. Olavs hospital og stipendiat ved Universitetet i Tromsø.

Forfatter har fylt ut ICMJE-skjemaet og oppgir ingen interessekonflikter.

Email: losvik@gmail.com

\section{Veien gjennom turnustjenesten føles som å løpe raskest mulig mellom skyttergravene for å unngå å bli skutt.}

Å være turnuslege er en eksperimentell læringsform. Fra dag til dag prøver jeg forskjellige utgaver av å være lege. Kunnskaper fra studiet ligger bak når jeg i møte med pasientene prøver ut ulike måter å utøve diagnostikk og behandling på. Jeg velger strategier ut fra det jeg kan og ut fra de tilbakemeldinger jeg har fått tidligere. Gjør man en feilvurdering, kommer det noen ganger tilbakemelding, som oftest på en gul lapp i journalsystemet.

Som en av de siste turnuslegene i den gamle ordningen er jeg nå godt over halvveis (1). Jeg roterer fra avdeling til avdeling og har jobbet sammen med hundrevis av kolleger. Talegjenkjenningen begynner nå å forstå meg, og ikke minst har jeg lært mange nye diagnosekoder som genererer flere inntekter til helseforetaket.

Nesten alle tilbakemeldinger jeg får, handler om manglende diagnosekoder i epikrisen. De andre tilbakemeldingene går stort sett på at man burde ha tatt blodgass eller ikke har bestilt tilstrekkelig med bildediagnostikk. I tillegg har jeg noen ganger fătt kopi av epikrisen til pasienter som har dødd under oppholdet.

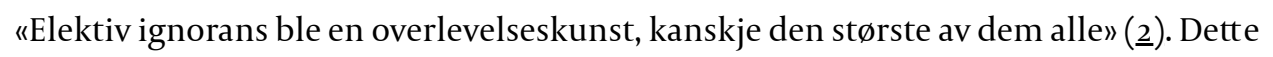
sitatet fra Jonathan Frantzens Korrigeringer er et bilde på den sosiale fordervelsen etter samfunnets "progresjon». Omorganiseringer, dokumentasjonskrav og tidspress gir moralsk stress hos over halvparten av norske leger, det gjelder også de yngre (3). Elektiv ignorans ble min måte å se bort fra tilbakemeldinger på, meldinger som jeg verken fant relevante eller konstruktive for jobben min eller opplæringen (4). Egentlig en ganske umoden mekanisme for å ta til seg kritikk.

Jeg er langt fra den første som spør etter spesifikke, relevante og konstruktive tilbakemeldinger $(5, \underline{6})$. Helsevesenet brukes ofte av pedagoger som eksempel på mestersvenn-læring. Som i håndverksfagene er både ferdigheter, kunnskaper og holdninger blitt overført fra en erfaren kliniker til en yngre lege. Jeg vet ikke om det er den oppnevnte 
veilederen min som skal regnes som min mester? Kanskje er det den overlegen som fra dag til dag er postoverlege? Jeg har i alle fall hatt ganske mange mestere i løpet av min svennetid på medisin.

Det har vist seg at leger er dårlige til å vurdere egne ferdigheter (7.). Veiledning og tilbakemeldinger blir derfor mer enn et spørsmål om opplæring, det er også et spørsmål om pasientsikkerhet. Korrigering underveis tror jeg er en viktig del av opplæringen av gode klinikere. Dessverre er inntrykket at tilbakemeldinger i dagens sykehusvesen er redusert til påpeking av feil. Ved også å komme med positive tilbakemeldinger vil man kunne gi langt flere korreksjoner - og ros når det er utøvd god klinisk praksis. God praksis er mye mer enn fravær av malpraksis.

Effektiviseringen av mitt universitetssykehus gjør at rapporteringen har forsvunnet. Før blodprøver og røntgenundersøkelser er tatt, har jeg diktert innkomstjournalen. Pasienten følges effektivt opp av neste lege uten at jeg trenger å tenke på det. Dermed er behovet for å konferere nesten borte. Borte er også en av de vanligste tilbakemeldingsarenaene. De fleste pasienter ser jeg aldri mer. Taushetsplikten er til hinder for at jeg skal få vite mer eller lære mer etter at mitt behandleransvar er over.

Både å gi og å få tilbakemeldinger er en ferdighet med et teoretisk rammeverk som kan læres $(\underline{8}, 9$. .). De beste tilbakemeldingene er de som initierer refleksjon. De beste refleksjonene vil både mester og svenn lære av - hvis de bare rekker det i et mer og mer industrialisert sykehusvesen.

Dersom arbeidsgivere og universiteter ser verdien av tilbakemeldinger som et middel til å få gode pasientbehandlere, må de også sette det på dagsordenen. Tilbakemeldinger og veiledning kan ikke bare være noe som skal gis etter at alle epikrisene er skrevet i god tid før sjudagersfristen. Kanskje har dette en plass på timeplanen sammen med både diaré og mikrobiologi?

Legelivet er vel som livet ellers. De fineste ordene kommer den siste dagen. Mye fint ble sagt på medisinsk avdeling da jeg var ferdig. Og egentlig har jeg fått skryt tidligere også. Hvis man skriver ut mange, får man gjerne rosende ord fra sykepleierne. Flere er også fornøyd med at jeg er veldig rask med pasientene i akuttmottaket. En gang døde pasienten min. Da fikk jeg gode tilbakemeldinger på morgenmøtet også. En klapp på skulderen for en tapt kamp.

Publisert først på nett.

\section{LITTERATUR}

1. Losvik OK. Ny turnustjeneste - ferske frustrasjoner. Tidsskr Nor Legeforen 2013; 133: 731. [PubMed]

2. Frantzen J. Korrigeringer. Oslo: Cappelen Damm, 2002.

3. Førde R, Aasland OG. Moralsk stress og faglig ytringsfrihet blant leger. Tidsskr Nor Legeforen 2013; 133: 1310-4. [PubMed]

4. Tunold O. Turnustjeneste er både læring og arbeid. Tidsskr Nor Lægeforen 2007; 127: 2118-20. [PubMed]

5. Bahar-Ozvaris S, Aslan D, Sahin-Hodoglugil N et al. A faculty development program evaluation: from needs assessment to long-term effects, of the teaching skills improvement program. Teach Learn Med 2004; 16:368-75. [PubMed] [CrossRef]

6. Bing-You RG, Trowbridge RL. Why medical educators may be failing at feedback. JAMA 2009; 302: 1330-1. [PubMed] [CrossRef]

7. Davis DA, Mazmanian PE, Fordis M et al. Accuracy of physician self-assessment compared with observed measures of competence: a systematic review. JAMA 2006; 296: 1094-102. [PubMed] [CrossRef]

8. Branch WT jr., Paranjape A. Feedback and reflection: teaching methods for clinical settings. Acad Med 2002; 77: 1185-8. [PubMed] [CrossRef]

9. Ende J. Feedback in clinical medical education. JAMA 1983; 250: 777-81. [PubMed] [CrossRef] 
Publisert: 3. september 2013. Tidsskr Nor Legeforen. DOI:10.4045/tidsskr.13.0826

Mottatt 24.6. 2013 og godkjent 14.8. 2013. Medisinsk redaktør Are Brean.

(C) Tidsskrift for Den norske legeforening 2023. Lastet ned fra tidsskriftet.no 26. april 2023. 